\title{
Leveraging the local: Cooperative food systems and the Local Organic Food Co-ops Network in Ontario, Canada
}

\author{
Jennifer Sumner ${ }^{a} *$ \\ University of Toronto \\ J. J. McMurtry
York University \\ Hannah Renglich ${ }^{\mathrm{c}}$ \\ Local Organic Food Co-ops Network
}

\begin{abstract}
Submitted September 9, 2013 / Revised November 14, 2013, January 16 and February 3, 2014 /
Accepted February 3, 2014 / Published online May 6, 2014

Citation: Sumner, J., McMurtry, J. J., \& Renglich, H. (2014). Leveraging the local: Cooperative food systems and the Local Organic Food Co-ops Network in Ontario, Canada. Journal of Agriculture, Food Systems, and Community Development, 4(3), 47-60. http://dx.doi.org/10.5304/jafscd.2014.043.004
\end{abstract}

Copyright (C) 2014 by New Leaf Associates, Inc.

\begin{abstract}
Cooperative food systems are based in cooperation, encourage inclusion, reconnect farmers and consumers, champion the local, and support more environmentally sustainable food systems. This exploratory research proposes a new economic framework for strategizing how to

\footnotetext{
a * Corresponding author: Jennifer Sumner, Adult Education and Community Development Program; OISE, University of Toronto; 252 Bloor Street West; Toronto, Ontario M5S 1V6 Canada; jennifer.sumner@utoronto.ca

b J. J. McMurtry, Business and Society Program, York University; S712 Ross Building, 4700 Keele Street; Toronto, Ontario M3J 1P3 Canada; imcmurtr@yorku.ca

c Hannah Renglich, Local Organic Food Co-ops Network, c/o Ontario Natural Food Co-op; 5685 McLaughlin Road; Mississauga, Ontario L5R 3K5 Canada; hrenglich@,onfc.ca
}

strengthen cooperative food systems. It also presents the example of a cooperative food system emerging in Ontario, Canada, the Local Organic Food Co-ops (LOFC) Network, to illustrate how to use the framework, drawing on the experience of the third author, who is the animator of the Network. Applying this analytical tool to the LOFC shows that the sixth cooperative principle - cooperation among cooperatives — is crucial for the viability of the Network, along with alliances and education. It also highlights the strength of horizontal linkages and the importance of leadership.

\section{Keywords}

cooperatives, cooperative food systems, economic theory of cooperative food systems, leakages, leveraging, linkages, local food, Local Organic Food Co-ops Network 


\section{Introduction}

Cooperative food systems involve a web of economic, social and environmental activities that focus on food. Unlike the dominant food system, which is based on competition and exclusion, cooperative food systems emphasize working together for mutual benefits based on democratically chosen goals. Although cooperative food systems encompass more than coop businesses, such enterprises have a strong claim to a central place in these food systems, in particular because of the cooperative principles that define their activities. There are four basic types of cooperative businesses involved in cooperative food systems at every point along the food chain from field to fork: producer, consumer, worker and multistakeholder.

One characteristic of cooperative food systems is an affinity for the local: local markets, local products, or local food hubs. This preference arises not only as a form of resistance to the placeless food associated with the dominant food system, but also as a conscious choice based on values beyond profit, such as democracy, community resilience, and environmental integrity. While it is true that some larger multinational cooperatives have become embedded in the dominant food system, other emerging and existing cooperatives remain central arteries for local food alternatives and the development of sustainable and democratic food systems.

One example of a cooperative food system is emerging in the province of Ontario. With the support of the Ontario Co-operative Association, the Local Organic Food Co-ops (LOFC) first convened in 2009. Now hosted and incubated by the Ontario Natural Food Co-op (ONFC), the LOFC Network (the term "Network" was added in 2011) includes over 40 member cooperatives. In this exploratory research, we will introduce this innovative enterprise to illustrate a new economic framework. We will also draw upon the experience of the third author, who is the animator of the LOFC Network, to show how this framework can be used for strategizing ways to strengthen cooperative food systems. We hope this framework will provide a practical analytical tool that is useful for the study of cooperative food systems in general and for practitioners who work in these systems in particular.

\section{Contextualizing Our Approach}

This paper is the first of a trilogy of papers on the future of cooperatives and alternative food systems. As such, it reflects the first stage of a longer project and represents exploratory research that can be built on. The second paper will entail an indepth case study of the Local Organic Food Coops Network; the third paper will address the larger question of the evolution of cooperatives.

In order to carry out this exploratory research, two scholars teamed up with a practitioner - the animator of the LOFC - who acted as a key informant. She provided information and knowledge that otherwise would have been difficult, if not impossible, to access. This close relationship with a practitioner was indispensable because it enabled us to use the LOFC to illustrate how to apply the new economic framework to strengthen cooperative food systems.

\section{Cooperative Food Systems}

A food system can be understood as an interdependent web of activities that include the production, processing, distribution, wholesaling, retailing, consumption, and disposal of food (Sumner, 2011). These activities can occur at a range of scales from the intensely local, as in the self-provisioning of small, isolated groups, to worldwide, as in the dominant food system. In the spirit of Born and Purcell (2006), no food system is inherently cooperative; the nature of a food system depends on the agenda of those who are empowered by the scalar strategy. In other words, both the local and global scales can be used to achieve certain goals, such as cooperation, but whatever is achieved will depend on the agenda of people who come to power because of a particular scale (e.g., global traders come to power in a global food system).

Following the definition of a food system, the dominant food system is the global corporate food system, which can be understood as an interdependent web of corporate-controlled activities at the global scale that include the production, processing, distribution, wholesaling, retailing, consumption, and disposal of food (Sumner, 2011). Based on intense competition, the global corporate food system has been described by Patel as a battlefield, where corporations "crack the supply 
chain like a whip" (2007, p. 99).

In contrast, a cooperative food system involves an interdependent web of mutually beneficial activities that include the production, processing, distribution, wholesaling, retailing, consumption, and disposal of food. It is based on a fundamental commitment to cooperation and democratic processes, while avoiding the winner-take-all competitive ethos that drives the dominant food system. In essence, a cooperative food system has a wider agenda than the dominant food system; it is interested in such aims as community economic development, social capital formation, just livelihoods, food security, and environmental care as much as profits. And like other food systems, cooperative food systems can occur at any scale: they can be part of a local food system and operate within a particular place; they can be part of a regional or national food system and serve those needs and aspirations; or they can be part of a worldwide system of cooperation, much like the fair-trade movement.

Cooperative food systems are both an ideal to work toward and an actually emerging system: as an ideal, they provide a model to emulate and a vision of a different reality; as an emerging system, they represent working alternatives to the dominant system and concrete proof that another world is possible. The wider agenda of cooperative food systems can align them more easily with the tenets of sustainable food systems, which are based on an understanding of sustainability that moves us beyond short-term profitability in ways that are environmentally sensitive, socially inclusive, and economically constructive (Clark \& Sumner, 2010) than with the tenets of the dominant food system, which is based on the exploitation of humans, animals, and the environment. This wider agenda, however, would be no guarantee of sustainability; that ultimately depends on the agenda of those empowered by the particular scale of the system.

Cooperative food systems can also be seen as a particular subset of alternative food networks (AFNs), which Sonnino \& Marsden (2006) propose can be variously and loosely defined in terms of quality, transparency, and locality. Renting, Schermer, and Rossi describe AFNs as a comprehensive term to describe "newly emerging net- works of producers, consumers, and other actors" (2003, p. 394). While AFNs can specialize in organics, fair trade, regional products, and/or artisanal products, Whatmore, Stassart and Renting argue that these networks share three commonalities: they redistribute value throughout the network; they reintroduce trust between producers and consumers; and they embody "new forms of political association and market governance" (2003, p. 389). The emergence of AFNs signals a shift from the industrialized and conventional food sector to a relocalized food and farming regime (Sonnino \& Marsden, 2006), which in turn nourishes "new market, state, and civic practices and visions" (Whatmore et al, 2003, p. 389).

Cooperative food systems include components such as community shops, allotment gardens, and community orchards (Beecher, Cato \& Weir 2012), as well as the social-economy organizations known as cooperatives.

\section{Cooperatives and Cooperation Among Cooperatives}

A cooperative is an autonomous association of persons united voluntarily to meet their common economic, social, and cultural needs and aspirations through a jointly owned and democratically controlled enterprise (International Co-operative Alliance, 2008). Some of the earliest retail cooperatives were formed in England to counter adulteration of food, and in Canada they were first established to protect farmers and fishers against the predations of big business (Sumner, 2012). Whether in the past or the present, cooperatives offer people a voice in an economic climate where individuals tend to be easily dominated or overlooked by powerful corporate players.

Food is well represented across the three main ownership structures common to cooperatives. Producer coops such as marketing coops put control in the hands of those who produce the food, and may include dairy coops and meat coops, as well as other types of food producers such as beekeepers. Worker coops involve enterprises owned by their workers, such as coffee shops, farms, grocery stores, and bakeries. Consumer coops provide a retail food outlet, often with benefits for members who shop there. Multistakeholder (also 
called solidarity or mixed) coops incorporate two or more of these classes of membership into one organization, in addition to other membership classes that may be relevant to the coop. Cooperative food hubs often utilize this model. Many coops are involved in the local food movement, as evidenced by research carried out by the Canadian Co-operative Association (CCA) that revealed that out of 2,300 local food initiatives in Canada in 2008, 227 (or 10 percent) were organized formally as cooperatives (Egbers, 2009).

For over a century cooperatives have followed the sixth principle of cooperation, "cooperation among cooperatives," and worked together in what Harter refers to as "nets of collective action" (2004, p. 96). These groupings can take different forms, such as federations, value chains, and networks (the focus of this paper). Whatever the form, these cooperative support organizations help their "constituent cooperatives survive by effectively consolidating resources in order to better intersect with organizations in a larger bureaucratic system" (Harter \& Krone, 2001, p. 249).

Some coops join together to form federations in order to match economic trends and betterintegrated competitors (Fairbairn, 2004). Gray (2008) describes federations as a cooperative of local coops, with the local organizations owning the federation, providing capital for its operation and electing a board of directors, which in turn hires the regional federation management. Federations coalesce around common interests and are based on principles such as "shared goals, relations built on trust, operational interdependence, subsidiarity, relative equality in size, and dialogue and discussion of norms and goals" (Johnstad, 1997, p. 57). One interesting example is the Federation of Southern Cooperatives. Founded in 1967, it brought together 100 farmer's cooperatives, marketing coops, and credit unions from across the southern United States (Nembhard, 2006). In essence, it "provides assistance to cooperatives involved in agricultural marketing, supply purchasing, and credit assistance" (Gilbert, Sharp \& Felin, 2002, p. 15), as well as foregrounding fair trade for farmers (Jaffee, Kloppenburg \& Monroy, 2004). Other examples include the Fédération des unions industrielles du Québec, the Ontario
Natural Food Co-op, and Federated Co-operatives Limited.

Groups of coops can also become part of value chains, which have recently emerged "as strategies for differentiating farm products and opening new, more financially viable market channels for smaller farmers" (Diamond \& Barham, 2011, p. 101). Stevenson, Clancy, King, Lev, Ostrom, and Smith argue that such value-chain business models emphasize the values associated not only with the food, but also the business relationships within the food supply chain. Within these relationships, they add, "farmers and ranchers are treated as strategic partners, not as interchangeable input suppliers" (2011, p. 27).

Some cooperatives - like the case described in this paper - have formed networks, which can be understood as a collection of relationships that connect groups and can both impose restraints that limit options and provide resources (Johnson, 2000). Unlike a federation, which is a cooperative owned by cooperatives, a network is a group of cooperatives that work together without establishing a lead coop. Birchall (1997) considers cooperative networks to be the first stage of developing a federation. Two examples include the Cooperative Network, an association committed to building cooperative businesses in Wisconsin and Minnesota (Co-operative Network, n.d.), and New York Cooperative Network, an organization for cooperative businesses and economic development (New York Cooperative Network, n.d.). While much has been written on coop federations (e.g., Birchall, 1997; MacPherson, 1979) and on value chains (e.g., Diamond \& Barham, 2011; Stevenson et al., 2011), little has been written about coop networks (see, for example, Beecher et al., 2012). Hingley is one of the exceptions, but his definition of a network is "a co-operative, its members, customers, suppliers and the community as a whole" (2010, p. 111), not a network made up exclusively of coops. This paper aims to fill this gap in the literature by introducing the Local Organic Food Co-ops Network. This emerging cooperative network dovetails with Renting and colleagues' (2012) contention that new types of networks associated with food are of particular interest for two reasons. First, they potentially represent a shift from consumers as passive 
end users toward more proactive citizen-consumers. Second, these new networks also point to potentially important changes with respect to the role and weight of different governance mechanisms within agri-food systems.

\section{The Local Organic Food Co-ops Network}

The burgeoning interest in local food in Ontario has spawned the Local Organic Food Co-ops Network. In February 2009 the Ontario Co-operative Association - a nonprofit organization that provides resources and a common voice for Ontario credit unions and cooperatives (On Co-op, n.d.) hosted a meeting in Toronto to bring together a number of new cooperatives with three established cooperatives to encourage information sharing and potential collaboration. The meeting had four objectives (Christianson, 2009). First, it aimed to help foster and maintain connections between cooperatives working in the areas of local and organic food and to provide sources of support for their work. Second, it planned to develop a strategy that would help coops grow by allowing them to share experiences and knowledge with each other. Third, it wanted to learn how the coop model was working in various communities, and how it could share those experiences with other communities across Ontario that are also interested in developing local organic food cooperatives. And fourth, it wished to provide board governance training and technical assistance. As a result of a follow-up meeting in April 2010, the Local Organic Food Coops initiative was born, to be housed and supported by the Ontario Natural Food Co-op (ONFC); the term "Network" was added at a $3^{\text {rd }}$ Assembly of the involved coops in 2011. The ONFC hired Hannah Renglich as the network "animator" in March 2011, to coordinate and develop all areas related to the Network as well as its relationship to the ONFC. The animator champions the roles and needs of the cooperatives within the cooperative movement and the food system, organizes academic research, creates opportunities for member-based and public education, advocates for policy change, supports emerging and transitioning cooperatives, and facilitates connections and relationship-building among the coops as well as between individual coops and partner organizations. The animator also builds the business, social, and environmental case for the continued existence of the Network within the ONFC (which now considers the LOFC as one of its strategic initiatives). In addition, the animator is responsible for ongoing contact with and animation of a growing network of cooperatives across Ontario, as well as sustained and reciprocal relationships with the Ontario Co-operative Association, Sustain Ontario, and multiple community partners.

In essence, the LOFC Network links cooperatively structured food and farming enterprises in the province of Ontario.

Through the sharing of information and exploration of innovations in food-based social enterprise, the co-ops are co-creating the network as a platform for internal strengthening and province-wide collaboration. (Renglich, 2012a)

This network of food and farming coops works toward "a co-operative and sustainable food system by strengthening the food co-op movement in Ontario" (Renglich, 2012a). From an initial group of 18 cooperatives, LOFC Network now includes over 40 active, incorporated, operating member coops in addition to 27 start-ups and potential members, and is still growing (see Figure 1).

The purpose of the Network is threefold: to educate about and advocate for local and organic agriculture and food coops; to facilitate and support the growth of existing coops; and to connect and scale up for regional food processing and distribution hubs (Renglich, 2012a). The values of the network are in keeping with the interests of the coop members: fair prices and income for farmers; fresh, healthy food for eaters; and fulfilling work and fair wages for workers (Renglich, 2012a). In spite of the variety of organizational models within the network - farmer-owned, eater-owned, worker-owned, and multistakeholder - all the coops have six common characteristics:

1. Bringing local farmers and eaters closer together; 
2. Growing and supplying fresh, healthy food locally;

3. Keeping money in the community;

4. Trading fairly, whether domestically or internationally;

5. Saving energy, building the soil, and protecting water; and

6. Celebrating good food, culture and community. (Renglich, 2012a)

How can we analyze cooperative food systems like the LOFC Network in a way that builds understanding and helps them to become viable alternatives to the dominant food system? To answer this question, we turn to the work of John Loxley.

\section{An Economic Framework of Linkages, Leakages, and Leverages in Cooperative Food Systems \\ In his book Transforming or Reforming Capitalism,} Loxley (2007) outlines some creative ways in which community economic development actors can conceptualize and develop their economic activity beyond isolated organizations operating in the market. In this section, we will explain some elements of Loxley's theory, and add to them, in order to place cooperative food systems within a larger economic framework. Such a framing is important because if cooperative food systems are going to "scale up" as well as "scale out" their role as an alternative to the unsustainable dominant food system, they need to be able to develop a

Figure 1. Community Food System Map of the Local Organic Food Co-ops Network

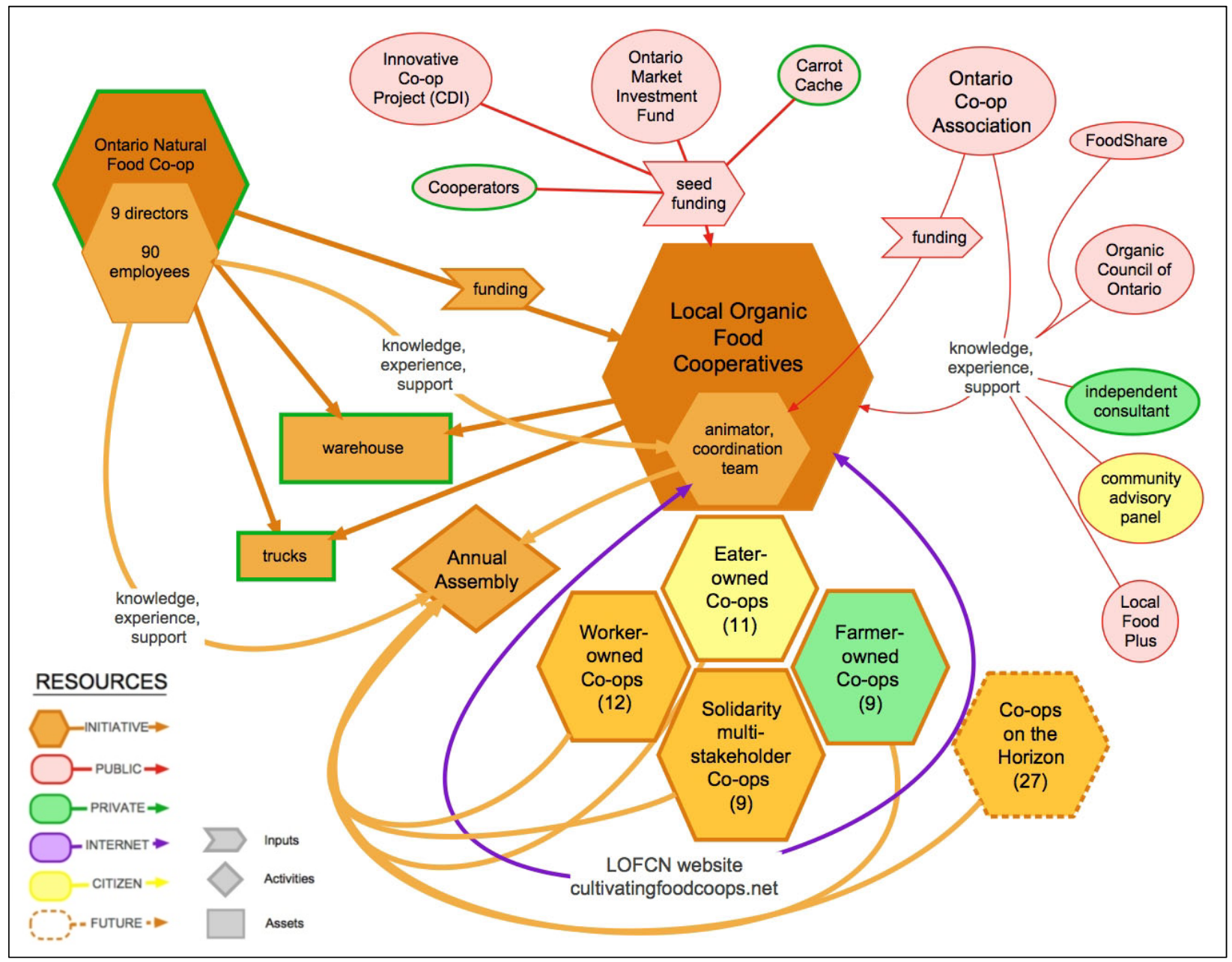

Used with the permission of Phil Mount. 
clear understanding of how they operate in the market.

What Loxley is especially interested in adopting from this theory is the idea of linkages backward linkages, forward linkages, and final demand linkages. These concepts, Loxley argues, can be applied at a local rather than a global level to illustrate how organizations focused on community economic development can both understand and scale up their activity. For example, a backward linkage measures how the demands of one sector (or, in our case, organization) can create economic benefit, and therefore strengthen, another sector (or organization). In the case of local organic food this could be the demand created by a local cooperative health food store for the local products of food producers in a particular geographic area. This backward-linked demand would strengthen the economic activity of the local organic food sector by linking two actors. Similarly, forward linkages measure how the outputs of one sector (or organization) connect to other sectors. In the case of local organic food this could be how the health food cooperative sells its goods on to local restaurants or community groups. Again, using the health food cooperative as a point of analysis, we can see how local food organizations can "link" their activities forward and backward to create a stronger local food sector. A final demand linkage is where the forward linkage stops, for example within the community or region. "The greater the proportion of domestic production sold inside the community or region, rather than as exports, the larger the final demand linkage effect will be" (Loxley, 2007, p. 61). For example, a local health food coop that caters to local residents creates a final demand linkage. The overall key for linkages is that the richer they are the greater the impacts of this alternative food system on the overall food system. In short, linkages are a way in which an alternative food system can be built, measured, and identified within economic discourse.

Further, what linkages provide as an economic theory for cooperative food systems is the idea that the sixth principle of cooperation, "cooperation among cooperatives," can be realized in economic practice. For example, credit unions (which are financial consumer cooperatives) have played and can play a key role in financing local food coopera- tives. Local food networks also provide an opportunity for other like-minded organizations to "link" together. The idea of local currency and the "multiplier effect" of local purchases (where dollars stay local rather than being sent to profit centers or investors) are two practical ways this happens. Finally, as some authors have argued (e.g., Restakis, 2010), "linked" cooperative economies are better able to withstand disasters - both human-made and natural.

Related to the concept of linkages is the concept of leakages. Just as linkages measure how sectors (or organizations) are connected, leakages measure how the opportunity for value capture by a sector (or organization) has been lost. In terms of cooperative food systems, it is where the dominant food system provides inputs into the local food system. While linkages indicate the strength of the local cooperative food system, leakages indicate its weakness. Such analysis can be crucial to the survival of a sector (or organization) because it shows where cooperative networks can intervene to transform leakages into linkages.

This concept however needs some refinement as we translate it from Loxley's (2007) community economic development focus to an analysis of cooperative food systems as we are moving from a consideration of a place to a consideration of a system. There may also be situations where apparent leakages would (or could) in fact be cooperative linkages. For example some fair trade goods produced by cooperatives (such as coffee, quinoa, or some teas and chocolate) are not available at the local or even regional level in many countries, but could be part of a richly linked and solidaristic international value chain of local cooperatives. The key here is to think of scaling-up and scaling-out cooperative food systems by linking smaller-scale producers, distributers and consumers in the cooperative world in order to facilitate a more sustainable, but diverse, global food system.

One final point on the re-articulated theory of linkages and leakages needs to be made. Loxley is clear that we cannot think of linkages or leakages solely in terms of products; we must also think in terms of "supply-side factors of production" (2007, p. 61) such as labor, capital, and even technology, and these can have either local or corporate pedi- 
grees. When considering cooperative food systems, therefore, we must also be thinking in terms of local labor, local capital, and local technical capacity being nurtured and developed. This is an important conceptual move to make for the local cooperative food movement, as too often the focus is on the local nature of the product, and not on the factors of production that allow for that local food to work its way through the linked value chain.

The third concept that we think is valuable for an economic theory of cooperative food systems is the concept of leveraging. While this concept does not come directly from Loxley's work, it does have its roots in his idea that communities need both to articulate to government bodies at every level the value of "small-scale production to meet local need" in economic terms in order to secure support through subsidies, and also, crucially, to articulate these demands as a united movement with the capacity for "collective action" (Loxley, 2007, p. 81). In other words, the smaller-scale economic entities that Loxley called community economic development organizations (or local organic food coops for the purposes of this paper) have to realize their capacity to improve their impacts and role in transformative change in the global food system by leveraging their potential power to influence public policy as a social movement. This is the political dimension of sustainable local food, the logical extension of their critique of the dominant food system. Without recognizing the need for both linked activities and action in the political realm, economic, social, and environmental transformations of existing unsustainable food systems are not possible.

The interrelated concepts of linkages, leakages and leveraging - the Three Ls - provide a promising new framework for strategizing how to strengthen cooperative food systems. In the next section, we draw on the experience of the third author, the animator of the LOFC Network, to illustrate how to use this practical analytical tool.

\section{Applying the Three Ls - Linkages, Leakages, and Leveraging - to the LOFC Network}

\section{Linkages}

Linkages are fundamental to the LOFC Network: the very name of the organization speaks to the value of linkages, with "network" as the resonant concept. This commitment, which reflects the sixth cooperative principle of cooperative solidarity, is evident in the LOFC Network's support of those member coops that wish to scale up their operations to the regional or national level. In addition to support in scaling up, the LOFC Network also supports coops that want to scale out by making important connections with other similarly valuesdriven actors (cooperatives). Scaling out involves increasing organizational capacity and building bridges both within and beyond the local community.

Even after four years of operation, the LOFC Network steering committee still places its greatest focus on networking, as it hears repeatedly from the membership that this function is paramount. These linkages enable learning in regional clusters, peer-to-peer skills sharing, mentorships, and reciprocal relationships throughout the cooperative supply chain, and collaboration between academics and the Network. For example, the LOFC Network has an academic constellation (Surman, 2006) - a loosely affiliated group of researchers, scholars, and educators who pursue studies in food and cooperation - which meets by phone semiregularly as well as at annual associational conferences. The importance of the linkages between community-driven cooperatives (practitioners) and academics cannot be overstated, and they often blend into leveraging. For example, as a result of these partnerships, the LOFC Network has collaboratively developed a list of priorities for research, as requested by the academic constellation, which in turn will help guide and generate research to push progressive policy forward to the benefit of the Network and its members.

The linkages at the LOFC Network facilitated through networking have created both physical and virtual spaces for connection that might not otherwise exist. The result is a complex system of cooperative organizations, with the animator working to draw the links between the nodes of the system, while facilitating and brokering dialogue. In terms of backward linkages, the host and incubator for the LOFC Network (and member of the Network), the Ontario Natural Food Co-op, provides a classic 
example. The ONFC distributes natural, organic, and local food to buying clubs, coops, natural health food retailers, restaurants, and grocery stores throughout Ontario and eastern Canada, as well as Manitoba and Alberta. Its mission is to support a sustainable food system "by providing, with integrity, quality service in the distribution of organic and natural foods and products within a socially responsible, cooperative network" (ONFC, n.d.). The ONFC has created its own private label for a number of products, including canned tomatoes, sauerkraut, frozen fruit, fish, beef, and tofu. This initiative of the ONFC has created demand for these unique products, which are exclusively grown, processed, and distributed within Ontario, and the ONFC anticipates supporting and contracting cooperatives of growers to supply the label, thus creating strong backward linkages to the benefit of producers and consumers of local and organic food. The ONFC also illustrates forward linkages in its role as a distributor that sells its private label products to many of the cooperatives in the Network. In this way, developing new retail cooperatives means creating more opportunities for forward linkages. Final demand linkages are created by, for example, consumer recognition of the ONFC brand.

Another set of linkages implied but not directly mentioned by Loxley (2007) are horizontal linkages, which connect similar organizations, unlike the vertical linkages through the supply chain represented by forward and backward linkages. Because of the complexities of stakeholdership in the LOFC Network (where most of the newest wave of developing coops are multistakeholders), eaters/consumers, producers/farmers, workers, community partners, commercial partners, and financial supporters/investors/contributors all sit at the table together and indeed ethically engender demand for and create a supply of local organic food.

\section{Leakages}

Although not always a negative occurrence, most leakages allow value to seep out of a food system, thus preventing some sectors or organizations from benefitting from that value. For the foreseeable future, however, cooperative food systems will have to work with and accommodate to (and even grow as a result of relationships with) the dominant food system; identifying leakages is a good way to highlight areas of potential cooperative food system development.

In terms of the LOFC Network, a number of leakages are evident. For example, the Ontario Food Terminal is "the 'stock exchange' for fruits and vegetables, where prices are determined by supply and demand and can change daily" (Ontario Food Terminal 2013). Food bought and sold through the Terminal represents both a leakage and a demand that the LOFC Network would like to fill. Recent power outages and flooding in Ontario have highlighted the fragility of having one central node through which most of the produce in the province moves. A more diffused and distributed mode of delivery with produce flowing directly from local farms to local retailers, as is the case for many of the local organic food coops, ensures diversity, redundancy and, thus, greater resilience in the local food system. A second example of leakages involves the high volume of goods from outside of Ontario sold by the ONFC. Such leakages could be mitigated by more linking within the province. A third example would include sales from non-cooperative entities such as grocery stores, which again could be addressed by more linkages.

A further leakage focuses on the loss of farmland in Ontario, which is being purchased for real estate or commercial development, often by foreign investors. This loss of an irreplaceable resource is compounded by the wave of retiring farmers. This means fewer farms and fewer farmers in the future. Coops like those in the Network can help to address the leakage of land, knowledge and skills for farming by being part of succession planning, thus providing opportunities for new entrants to farming to access land more affordably and cooperatively (On Co-op, 2013).

A final leakage centers on the loss of traditional knowledge as well as access to traditional land across communities in Ontario that rely on freshwater and forest foods for sustenance. This leakage is created by increasing governmental controls, regulations and legislation, which prevent access to traditional lands, create prohibitive costs 
associated with hunting, fishing, trapping and foraging, and in general toxify forest and freshwater foods upon which First Nations and far Northern communities are so reliant. This leakage of control, self-determination, and autonomy is being addressed by the newest wave of coop development that the LOFC Network is supporting in Northern and First Nations communities (see, for example, Mackenzie, 2013).

\section{Leveraging}

Leveraging involves using a collective voice to articulate to all levels of government the importance of small-scale production to meet local needs, in order to garner material resources. As a young organization, the LOFC Network has not yet been able to engage in a great deal of leveraging on its own. However, it has made a number of strategic partnerships with other organizations that do have high leverage capacity. These organizations (Sustain Ontario, the Alliance for Healthy Food and Farming, and the Ontario Co-operative Association) help the LOFC Network with advocacy and engage in reciprocal and mutually beneficial leveraging. The Network has also made a strategic partnership with the Neighboring Food Co-op Association (NFCA), a group of 30 retail "food coops and start-up initiatives in New England that are working together toward a shared vision of a thriving regional economy, rooted in a healthy, just and sustainable food system and a vibrant community of co-operative enterprise" (NFCA, 2013, para. 1). The NFCA has been a collaborative partner in LOFC Network governance development, offering dialogue, documents, and its operational model for the Network's consideration and emulation, where applicable.

In essence, the linkages represented by such partnerships represent one of the strongest leveraging tools the LOFC Network uses. By participating in partnerships, the Network avoids "reinventing the wheel," performing the very value it promotes to its membership. Through collaboration, the Network gains awareness of new projects, leverages opportunities to meet, train, and educate its members through other events, supports others' work through letters of support, direct action, and collaborative grant proposals, develops a presence at a variety of conferences, and partners in advocacy work and policy promotion.

The LOFC Network has also been able to use various forms of media, including social media, film, and its own website, to leverage its impact. In 2012, the Network made three short films with Sustain Ontario and Powerline Films, in collaboration with the Ontario Co-operative Association, the Canadian Co-operative Association and the Ontario Natural Food Co-op, to highlight the work and potential of the Network through conversation with members. In 2013, a cycling and cooperative food enthusiast made contact with LOFC Network after following its Twitter feed, attending the $4^{\text {th }}$ Annual Assembly and embarking on a bicycle tour of many of the food coops in the network. His ride has brought coops closer together as he shares stories along the way and organizes to present a SWOT analysis (i.e., an analysis of strengths, weaknesses, opportunities and threats) and a webinar about his tour through the Ontario Co-operative Association. Finally, a ministry in the provincial government was so impressed by the LOFC Network website that it has strongly encouraged the Network to apply for funding for expansion and development.

The LOFC Network also engages in some mutual leveraging with the academic constellation in pursuit of a more just and localized food system. The constellation leverages LOFC Network resources to determine research priorities, and the LOFC Network leverages the constellation to appeal for small amounts of funding for such research, or for partnerships to carry out work that it deems important.

The linkages among the coops in the Network allow many of them to leverage one another's events. For example, if there is a film night at a coop in St. Catharines, coop members from Fort Erie and Niagara Falls will certainly be there in support. Additionally, when the LOFC Network seeks outside expertise, it always approaches those within the Network first before seeking outside cooperative expertise. For example, at the LOFC's $3^{\text {rd }}$ Annual Assembly, it ran a farmer-training stream for developing organic businesses with Richard Wiswall, whose Cate Farm is a long-time member of Deep Root Organic Co-op. 
Finally, the Network places a tremendous value on using its linkages to leverage common resources. For example, the Mustard Seed (a nascent coop in Hamilton) has been developing a local supplier list for its store opening, which has been freely shared with other coops in the region for their input and additions. The LOFC Network hopes to be able to eventually leverage shared benefits and insurance for all its members as it stabilizes and grows.

\section{Discussion}

The new economic framework of the Three Ls linkages, leakages, and leveraging — represents an analytical tool that will be beneficial to both scholars and practitioners. Using the Local Organic Food Co-ops Network to illustrate how to apply it yields some instructive insights that could help to strengthen cooperative food systems.

First and foremost is the crucial importance of the sixth cooperative principle: cooperation among cooperatives. Without this spirit of solidarity, the LOFC Network would not be viable. As an antidote to the taken-for-granted competition that characterizes both local and global markets, cooperation helps cooperatives like those in the Network to "survive and meet the needs of members in an ever more competitive global economy" (Birchall, 1997, p. 70). An examination of the linkages involved in the LOFC Network illustrates the extent of the cooperation within the Network. The greater the strength and number of linkages, the greater the opportunities for establishing new cooperatives that will continue to build the Network. This is especially true for financing - an age-old problem for cooperatives - which could be substantively improved by cooperation among cooperatives using a variety of financial support vehicles, such as loans, investments, and expertise, in essence enabling access to the factors of production. It is interesting to note that Birchall maintains that the traditional way of achieving cooperation among cooperatives has been by forming federations, "but this model of organisation may now be too slow and inflexible to cope with a rapidly changing business environment, and a search is on for more effective ways in which coops can co-operate" (1997, p. 70). Networks such as the LOFC Network may be one of the answers to this problem. Their lack of entrenched bureaucratic structures and fluidity of form can make them more nimble in a quickly changing market.

The second insight involves the importance of alliances - strategic partnerships between coops and other types of organizations, and how they promote leverage. The alliances the LOFC Network has forged with Sustain Ontario (an umbrella organization that includes the Alliance for Healthy Food and Farming and the Ontario Co-operative Association) have helped it to leverage its position as a new entrant on the local food scene, allowing it to achieve greater visibility and support transformative change in the food system. These alliances are facilitated by the fact that the LOFC Network is part of the flourishing local food and food sovereignty movements, made up of myriad actors who are interested in challenging the dominant food system and re-embedding food within local markets. Committed membership in these social movements enhances the Network's potential to influence public policy regarding the importance of small-scale production for local need, as well as encouraging agency and empowerment.

The third insight is the importance of education in terms of the supply-side factors of production - an essential aspect of linkages. The emphasis on networking has resulted in educational forums, skills-sharing, mentorships, and community-university relationships, all of which build the linkages that help local food move through the local value chain. This is also in keeping with the fifth cooperative principle: education, training, and information. Education is vital, not only for the local food movement, but also for cooperative organizations like the LOFC Network. For example, through various types of leakages, money and jobs flow out of the local economy, but this can be staunched by a cooperative food economy, which keeps greater value within the community, thus promoting an alternative food network. In terms of money, a recent study found that the value farmers receive for their products is higher from coops compared to the dominant retail system: Canada's farmers receive only twenty cents of every consumer food dollar, while local organic food coops 
provide farmers with sixty cents or more of the consumer food dollar (see Renglich, 2012b). But many farmers do not realize this, which provides an educational opportunity for cooperative food systems. In terms of jobs, worker coops like those in the LOFC Network can offer a more just and dignified form of labor, which links them with another social movement - the food justice movement. Indeed, some coops are formed to create employment. In the midst of the so-called "jobless recovery," it is important that cooperative food systems spread the word about the employment benefits of coops.

Another interesting insight is the strength of horizontal linkages. As coops evolve and work together, these types of relationships will become more important, laying the ground for future linkages of all kinds. The explicit recognition of horizontal linkages also adds breadth to the economic framework, making it more robust and more representative of the realities within cooperative food systems.

The final insight involves the importance of leadership, both by the ONFC and the animator. As a potential factor of production, leadership provides the ability for the Network to incubate, coordinate, organize, communicate, and move forward. Following the Strawberry Patch model of cooperative development, which encourages the growth of satellite organizations, the LOFC Network is working hard to encourage leadership at the level of each cooperative, creating space for leaders to emerge and opportunities for leadership skills to develop. Cooperatives, especially emerging coops, grow organically and without a great deal of interaction with each other. As a result, they tend to "reinvent the wheel," at least in their early stages. Leadership from and for a coalescing sector is therefore central in leveraging the strengths of many disparate groups for a cooperatively agreedupon goal - in this case, the goal of establishing a cooperative food system. The LOFC Network is demonstrating this reality on the ground in Ontario.

Using the LOFC Network to illustrate how to use the economic framework has yielded instructive insights into the creation, maintenance, and expansion of cooperative food systems. Such alter- natives are crucial to countering the negative economic, social, and environmental effects of the dominant food system, and help to address "the increased interest in non-competitive models disavowing the routine exploitation of resources and people" (Broadhead \& Morrison, 2012, p. 1). Grounded in the local, cooperative food systems exhibit the potential depth, breadth, and reach to build a solidaristic international food economy that turns value chains into values chains and operates by the principle of cooperation.

\section{Conclusion}

This paper represents exploratory research that others can build on in the future. In essence, it develops a practical analytical tool and offers the example of the Local Organic Food Co-ops Network to illustrate how to use it. This tool could prove beneficial not only for scholars who study cooperative food systems, but also for practitioners in their day-to-day work.

In light of the insights we gleaned, we offer the following recommendations for further research and practice, all of which aim to strengthen cooperative food systems. In terms of research, cooperative food systems are a nascent academic interest and more studies in this interdisciplinary area would help to build the case for these alternatives to the dominant food system. In addition, investigations of other cooperative networks would help to build a more accurate picture of cooperative food systems. And finally, applying the Three Ls to other cooperative food systems would enhance the robustness of this new analytical tool, testing its ability to assess strengths and weaknesses, build understanding, and scale cooperative enterprises up and out.

In terms of practice, a number of recommendations can be made. First, although it may seem to entail more work for an already-overworked coop to join a network, being a member brings advantages to both the individual cooperative and the system as a whole. Second, alliances with likeminded entities are crucial, especially in terms of leveraging. Third, educating members helps to address the supply-side factors of production. Fourth, it is vital that a cooperative food system has strong, committed, and enlightened leadership, 
whatever form it takes. And fifth, identifying the leakages in the cooperative enterprise and replacing them with linkages will help groups of coops to better understand their operations in the market and scale up or out, if desirable.

\section{References}

Beecher, J., Cato, M. S., \& Weir, N. (2012). The resilience of co-operative food networks: A case study from Stroud, England. In D. McDonnell \& E. Macknight (Eds.), The Co-operative Model in Practice: International Perspectives (pp. 53-66). Glasgow: Co-operative Education Trust Scotland.

Birchall, J. (1997). The international co-operative movement. Manchester, UK: Manchester University Press.

Born, B., \& Purcell, M. (2006). Avoiding the local trap: Scale and food systems in planning research. Journal of Planning Education and Research, 26(2), 195-207. http://dx.doi.org/10.1177/0739456X06291389

Broadhead, L.-A., \& Morrison, R. (2012). "Peace based on social justice": The ALBA alternative to corporate globalization. New Global Studies, 6(2), 130. http://dx.doi.org/10.1515/1940-0004.1153

Christianson, R. (2009). Creating a sustainable food system for Ontario: Supporting the development of local organic food cooperatives (Unpublished discussion paper compiled for the Ontario Co-operative Association).

Clark, E. A., \& Sumner, J. (2010). Ontario, Canada: Lessons in sustainability from organic farmers. In S. R. Gliessman \& M. Rosemeyer (Eds.), The Conversion to Sustainable Agriculture: Principles, Processes, and Practices (pp. 133-164). Boca Raton, Florida: CRC Press.

Cooperative Network. (n.d.). Who are we? Retrieved January 13, 2013 from http://www.cooperativenetwork.coop/wm/news/ aboutcoops/web/coopnetoverview.html

Diamond, A., \& Barham, J. (2011). Money and mission: Moving food with value and values. Journal of Agriculture, Food Systems and Community Development, 1(4), 101-117. http://dx.doi.org10.5304/jafscd.2011.014.013

Egbers, A. (2009). The lay of the land: Local food initiatives in Canada. Ottawa, Ontario: Canadian Co-operative Association. Retrieved from http://www.coops canada.coop/assets/firefly/files/files/The Lay of the Land Final June 16 2009.pdf

Fairbairn, B. (2004). History of co-operatives. In C. D. Merrett \& N. Walzer (Eds.), Cooperatives and local development: Theory and applications for the $21^{\text {st }}$ century (pp. 23-51). New York: M. E. Sharpe.

Gilbert, J., Sharp, G., \& Felin, M. S. (2002). The loss and persistence of black-owned farm and farmland: A review of the research literature and its implications. Southern Rural Sociology, 18(2), 1-30.

Retrieved from

http://www.ag.auburn.edu/auxiliary/srsa/pages/A rticles/SRS $\% 202002 \% 2018 \% 202 \% 201-30 . p d f$

Gray, T. W. (2008). The agriculture of the middle initiative: Premobilizing considerations and formal co-operative structure. Saskatoon, Saskatchewan: Centre for the Studies of Co-operatives, University of Saskatchewan. Retrieved from http://usaskstudies. coop/pdf-files/publications/2009/Agriculture_ of the Middle.pdf

Harter, L. M. (2004). Masculinity(s), the agrarian frontier myth, and cooperative ways of organizing: Contradictions and tensions in the experience and enactment of democracy. Journal of Applied Communication Research, 32(2), 89-118. http://dx.doi.org/10.1080/0090988042000210016

Harter, L., \& Krone, K. J. (2001). The boundaryspanning role of a cooperative support organization: Managing the paradox of stability and change in non-traditional organizations. Journal of Applied Communication Research, 29(3), 248-277. http://dx.doi.org/10.1080/00909880128111

Hingley, M. (2010). Networks in socially embedded local food supply: The case of retailer co-operatives. Journal of Business Marketing Management, 4(3), 111128. http://dx.doi.org/10.1007/s12087-010-0036-2

International Co-operative Alliance. (n.d.). Co-operative identity, values \& principles. Retrieved April 17, 2014, from http://ica.coop/en/whats-co-op/cooperative-identity-values-principles

Jaffee, D., Kloppenburg, J. R. Jr., \& Monroy, M. B. (2004). Bringing the "moral charge" home: Fair trade within the north and within the south. Rural Sociology, 69(2), 169-196. Retrieved from http://www.dev.cftn.ca/sites/default/files/Acade micLiterature/Bringing $\% 20$ the $\% 20 \% \mathrm{E} 2 \% 80 \% 98 \mathrm{M}$ oral $\% 20$ Charge.pdf

Johnson, A. G. (2000). The Blackwell dictionary of sociology: A user's guide to sociological language. Malden, Massachusetts: Wiley-Blackwell.

Johnstad, T. (1997). Co-operatives and federations. Journal of Co-operative Studies, 89, 48-60. 
Loxley, J. (Ed.) (2007). Transforming or reforming capitalism: Towards a theory of community economic development. Halifax: Fernwood Publishing.

Mackenzie, K. (2013, May 3). Eat Local Sudbury Co-op and True North Community Co-op support each other! Retrieved from the LOFC Network website: http://cultivatingfoodcoops.net/news/helping/nor thern-ontario-local-economy-co-ops-happytogether/

MacPherson, I. (1979). The co-operative movement on the Prairies: 1900-1955 [Historical Booklet No. 33]. Ottawa: Canadian Historical Association.

Nembhard, J. G. (2006). Principles and strategies for reconstruction: Models of African American community-based cooperative economic development. Harvard Journal of African American Public Policy, 12, 1-18. http://community-wealth. org/sites/clone.community-wealth.org/files/ downloads/article-nembhard06.pdf

Neighboring Food Co-op Association [NFCA]. (n.d.). Neighboring Food Co-op Association. Retrieved in 2013 from http://nfca.coop

New York Cooperative Network. (n.d.). Home. Retrieved in 2013 from http://www.newyorkcooperative.net/

On Co-op. (2013). Succession planning [Brochure]. Guelph, Ontario: Ontario Co-operative Association. Retrieved from http://www.ontario.coop/

On Co-op. (n.d.). About us. Ontario Co-operative Association. Retrieved January 13, 2013 from http://www.ontario.coop/about us

Ontario Food Terminal. (n.d.). Welcome to the Ontario Food Terminal Board. Retrieved January 13, 2013, from http://www.oftb.com/home

Ontario Natural Food Co-op [ONFC]. (n.d.). Our Mission. Retrieved April 22, 2014, from http://www.onfc.ca/sites/default/files/buyingclub $\angle$ Buying $\% 20$ Club $\% 20$ Basics $\% 20 . p d f$

Patel, R. (2007). Stuffed and starved: Markets, power and the bidden battle for the world food system. Toronto: HarperCollins.
Renglich, H. (2012a, May 15). Welcome. Retrieved from the LOFC Network website: http://cultivatingfood coops.net/uncategorized/welcome-bienvenue-2/

Renglich, H. (2012b, November). Co-operative approaches to alternative food and farm initiatives: This is democracy? Presented at the Food Secure Canada conference, Edmonton, Alberta.

Renting, H., Schermer, M., \& Rossi, A. (2012). Building food democracy: Exploring civic food networks and newly emerging forms of food citizenship. International Journal of Sociology of Agriculture and Food, 19(3), 289-307.

Restakis, J. (2010). Humanizing the economy: Co-operatives in the age of capital. Gabriola Island, British Columbia: New Society Publishers.

Sonnino, R., \& Marsden, T. (2006). Beyond the divide: Rethinking relationships between alternative and conventional food networks in Europe. Journal of Economic Geography, 6(2), 181-199. http://dx.doi.org/10.1093/jeg/lbi006

Stevenson, G. W., Clancy, K., King, R., Lev, L., Ostrom, M., \& Smith, S. (2011). Midscale food value chains: An introduction. Journal of Agriculture, Food Systems and Community Development, 1(4), 27-34. http://dx.doi.org/10.5304/jafscd.2011.014.007

Sumner, J. (2011). Serving social justice: The role of the commons in sustainable food systems. Studies in Social Justice, 5(1), 63-75. http://ojs.uwindsor.ca/ ojs/leddy/index.php/SSJ/article/view/3114

Sumner, J. (2012). Dining on the social economy: Challenges and opportunities for local, sustainable food policy in a global context. Canadian Review of Social Policy, 67, 30-43. http://pi.library.yorku.ca/ ojs/index.php/crsp/index

Surman, T. (2006). Constellation collaboration: A model for multi-organizational partnership. Retrieved from the Centre for Social Innovation website: http://s.socialinnovation.ca/ files/Constellation $\% 2$ 0Model \%20Description \%20June \%209'06.pdf

Whatmore, S., Stassart, P., \& Renting, H. (2003). What's alternative about alternative food networks? [Guest editorial]. Environment and Planning A, 35(3), 389391. http://dx.doi.org/10.1068/a3621 